\title{
Nutrient enrichment of estuarine submersed vascular plant communities. 1. Algal growth and effects on production of plants and associated communities*
}

\author{
Robert R. Twilley ${ }^{1}$, W. Michael Kemp ${ }^{1}$, Kenneth W. Staver ${ }^{1}$, \\ J. Court Stevenson ${ }^{1} \&$ Walter R. Boynton ${ }^{2}$ \\ ${ }^{1}$ Horn Point Laboratories, Box 775, Cambridge, Maryland 21613, USA \\ ${ }^{2}$ Chesapeake Biological Laboratory, Box 38, Solomons, Maryland 20638, USA
}

\begin{abstract}
Eight experimental ponds containing submersed vascular plants (predominantly Potamogeton perfoliatus and Ruppia maritima) were subjected in duplicate to 4 levels (including controls) of fertilization from June to August 1981. Seston and phytoplankton chlorophyll a increased with fertilization, and pronounced algal blooms were evident under high dosage. Of the total seston, phytoplankton exerted the greatest influence on attenuation of photosynthetically active radiation (PAR), such that there was insufficient light for submersed vascular plant growth at the sediment surface during blooms. An extensive epiphytic community developed on plants in all nutrient-treated ponds at densities similar to those observed in nature on senescent plants. At high nutrient treatments the accumulation of epiphytic material resulted in $>80 \%$ attenuation of the incident radiation at the leaf surface. Biomass of submersed macrophytes decreased significantly under high and medium nutrient treatments compared to control and low treatments within $60 \mathrm{~d}$ following initial fertilization. Apparent production of vascular plants (based on oxygen production and ${ }^{14} \mathrm{C}$-bicarbonate uptake) was reduced at the higher nutrient treatments for both $R$. maritima and $P$. perfoliatus. Most of this reduction in macrophyte photosynthesis could be explained by attenuation of PAR associated with epiphytic material. However, without PAR attenuance in the overlying water, observed levels of epiphytic growth would be insufficient to reduce light below compensation levels needed to sustain vascular plant growth. At the high fertilization rates, integrated primary production of pond communities was significantly reduced with the loss of the vascular plants, even though phytoplankton and epiphytic growth were enhanced.
\end{abstract}

\section{INTRODUCTION}

The importance of submersed vascular plants in primary and secondary production has been recognized in a variety of aquatic ecosystems (e.g. Wood et al. 1969, Thayer et al. 1975, Kemp et al. 1984). Although submersed macrophytes are abundant in fresh, brackish and marine waters, the vast majority of research on these plants has been confined to lacustrine and marine systems (Kemp et al. 1983). Marked declines in abundance of submersed plants in many areas (e.g. Lind \& Cottam 1969, Den Hartog \& Polder-

\footnotetext{
- Contribution No. 1593 from the Center for Environmental and Estuarine Studies, University of Maryland, USA
}

man 1975, Perés \& Picard 1975, Jupp \& Spence 1977b, Dale \& Miller 1978, Phillips et al. 1978, Stuckey 1978) have served to focus worldwide attention on these macrophytes. Recently, reductions in populations of 10 to 15 species have occurred in a large estuarine system, Chesapeake Bay (Bayley et al. 1978. Stevenson \& Confer 1978, Orth \& Moore 1983).

It has been postulated that many of these losses of submersed plants were attributable to cultural eutrophication (e.g. Phillips et al. 1978, Cambridge 1979). The hypothesized mechanisms whereby nutrient additions could lead to reductions in submersed plants involve the promotion of algal growth, either phytoplanktonic (Jupp \& Spence 1977a) or epiphytic (Phillips et al. 1978), and a resulting reduction in light 
available to the vascular plants (Penhale 1977, SandJensen 1977). Additional stress mechanisms such as inhibition of molecular transport across plant epidermal surfaces may be involved as well (Sand-Jensen 1977).

Much of the information regarding nutrient effects on these algal-plant relations has been inferred from indirect correlative evidence along natural nutrient gradients (e.g. Cattaneo \& Kalff 1980, Sand-Jensen \& Søndergaard 1981). Direct experimental approaches have been applied for freshwaters utilizing pond or pool microcosms (Smith \& Swingle 1941, Mulligan \& Baranowski 1969, Ryan et al. 1972, Moss 1976, Mulligan et al. 1976, Phillips et al. 1978). Yet, similar investigations using marine or estuarine systems are lacking. In general, these studies have described effects of fertilization on algal and vascular plant growth or abundance, but few have examined interactive mechanisms directly

In the present study we utilize large experimental estuarine ponds to investigate the effects of nutrients on submersed vascular plant communities. Here we test the hypothesis that the decline in these plant communities as a result of fertilization can be explained in terms of increases in epiphytic algal and planktonic biomass, which decrease the available light to leaves for macrophyte productivity.

\section{MATERIALS AND METHODS}

Experimental systems and design. Eight rectangular ponds ( 27 by $13 \mathrm{~m}$ at water surface; sides sloped 1:1; mean depth and volume at maximum water height 1.2 $\mathrm{m}$ and $340 \mathrm{~m}^{3}$, respectively) were constructed at Horn Point Laboratories $\left(38^{\circ} 35.4^{\prime} \mathrm{N}, 76^{\circ} 0.7^{\prime} \mathrm{W}\right)$ during spring and summer of 1979 (Fig. 1). Water from the Choptank River estuary was pumped to each pond via a centrally located reservoir, entering through a control valve and exiting through a standpipe, so that flushing rate and water level could be controlled. Each pond has 3 piers, located at opposite ends and midway along one side, that facilitated sampling (Fig. 1).

Ponds were stocked with submersed vascular plants during summer 1979 from coves located along the Choptank River estuary. Sediment cores $15 \mathrm{~cm}$ diameter, $30 \mathrm{~cm}$ deep) containing plant shoots, roots and sediments were transported to the ponds, where they were transplanted in a grid with $1 \mathrm{~m}$ distance between adjacent plugs. Dominant transplanted species were Potamogeton perfoliatus var. bupleuroides (Fernald) Farwell and Ruppia maritima L. By summer 1980, about 50 to $80 \%$ of the sediment surface area was covered by these vascular plants, with other species (including Zannichellia palustris L., Myriophyllum

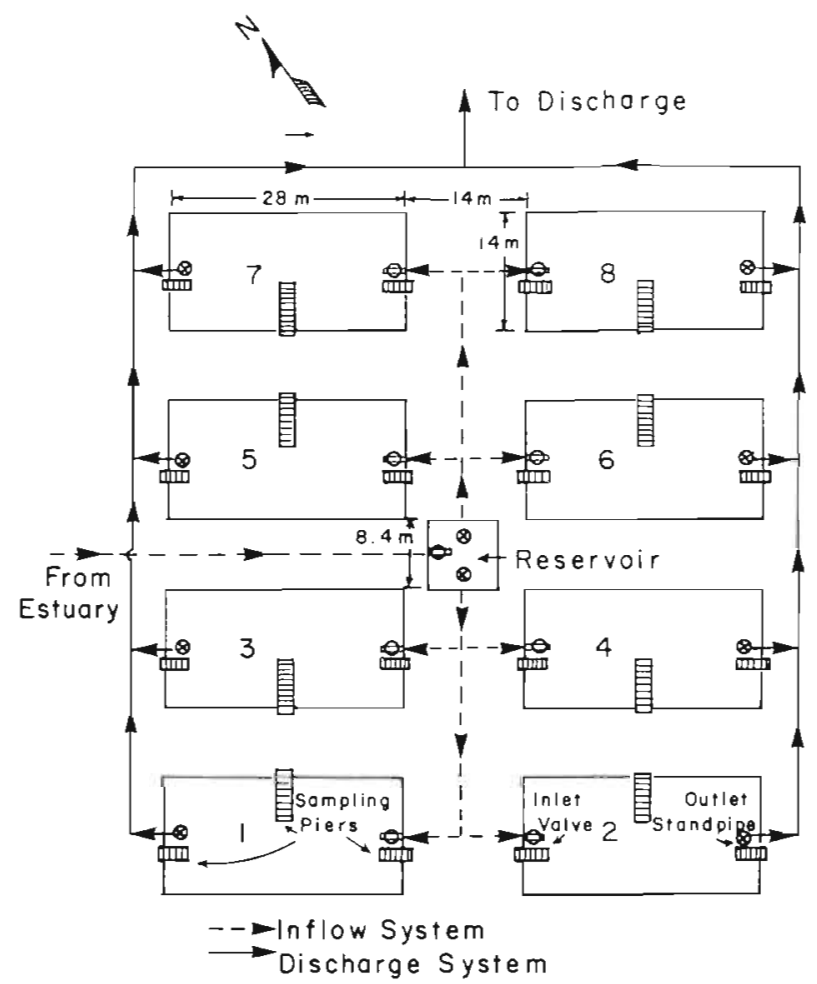

Fig. 1. Diagram of experimental ponds at Horn Point Environmental Laboratories. Broken lines: flow of water from Choptank River estuary; solid lines with arrows: flow to estuary

spicatum L., Elodea canadensis Michaux) at much lower densities. Salinities in the ponds ranged from 10 to $12 \%$ during this study, and the experimental macrophyte communities were typical of those encountered in most of Chesapeake Bay between 5 to $15 \%$.

Ponds were randomly assigned to a specific treatment, where 3 levels of dissolved nutrients were applied to duplicate ponds, and 2 untreated ponds served as controls. Commercial fertilizers in the form of ammonium sulphate, potassium nitrate, and diammonium phosphate contained equal amounts of $\mathrm{NO}_{3}^{-}$and $\mathrm{NH}_{4}^{+}$, and phosphorus (P) was added in 10:1 (atom) ratio. The nominal concentrations of inorganic $\mathrm{N}$ immediately after dosing were 120,60 , and $30 \mu \mathrm{M}$ in the high, medium, and low dose ponds, respectively. Loading rates for each respective treatment were 1.68, 0.84 and $0.42 \mathrm{gN} \mathrm{m}^{-2} \mathrm{~d}^{-1}$, and $0.37,0.19$ and $0.09 \mathrm{gP}$ $\mathrm{m}^{-2} \mathrm{~d}^{-1}$. Treatments, designed to mimic pulse runoff events, were administered on 6 occasions at $10 \mathrm{~d}$ intervals beginning 19 June 1981 and ending 4 August 1981. The ponds were held in batch mode for 8 to $9 \mathrm{~d}$ after each application, followed by a complete turnover of volume with ambient estuarine water.

Biomass of plants and epiphytes. Submersed aquatic vegetation was sampled in each pond twice before fertilization began, twice during the treatment period and once during post-treatment in November. A 
stratified random sampling procedure was used to select six $0.1 \mathrm{In}^{2}$ vegetated plots in each pond. Aboveground (leaves and stems) and belowground (roots and rhizomes) biomass samples were harvested on 17 June, whereas only aboveground material was sampled on the other occasions. Plant samples were rinsed with estuarine water to remove epiphytic material, sorted by species, and dried at $60^{\circ} \mathrm{C}$ to constant weight. Percent cover of vascular plants in each pond was determined by low altitude $(150 \mathrm{~m})$ aerial photography on each sampling date.

Weight and chlorophyll a content of epiphytic material attached to plant leaves was measured at each sampling of vascular plant biomass (except for the first and last). Individual plants were sampled in triplicate and placed in 11 plastic bottles. Epiphytes were removed by vigorously agitating the bottles for several minutes, and 3 subsamples were filtered (GF/C) in duplicate for analysis of chlorophyll a and total suspended solids. Microscopic examination $(200 \times)$ revealed that this procedure was effective in removing $>95 \%$ of material from plant leaves (Staver 1984). Filters for chlorophyll a analysis were wrapped in aluminum foil and frozen, and the others were dried to constant weight (ca $48 \mathrm{~h}$ ) at $60^{\circ} \mathrm{C}$. Levels of epiphytic material were corrected for background concentrations of chlorophyll a and total suspended solids of pond water. The plants from which epiphytic material was removed were dried in a plant press, weighed, and analyzed for leaf area with a LICOR Model 3100 area meter.

Productivity and respiration. Primary production and respiration of vascular plants and epiphytes were measured using both dissolved oxygen $\left(\mathrm{O}_{2}\right)$ and ${ }^{14} \mathrm{C}$ techniques. Metabolism of the apical 10 to $15 \mathrm{~cm}$ from apical tip) and basal (15 to $30 \mathrm{~cm}$ from apical tip) sections were compared among the fertilization treatments. Changes of $\mathrm{O}_{2}$ in clear and opaque $300 \mathrm{ml} B O D$ bottles filled with filtered $(\mathrm{GF} / \mathrm{C})$ estuarine water and containing $15 \mathrm{~cm}$ sections of plants with and without epiphytes were used as estimates of apparent production (in excess of respiration) and dark respiration, respectively. Potential problems with storage and transport of $\mathrm{O}_{2}$ in plant lacunae appear to have been unimportant with these species (Nixon \& Oviatt 1972, Westlake 1978, Lewis 1980, Sand-Jensen et al. 1982).

Apparent photosynthesis and respiration were also measured for epiphytic material removed (as above, by vigorous agitation) from a given plant, and this value was subtracted from rates for plants with their epiphytes intact to determine the contribution of macrophytes alone. Weight of epiphytic material on the vascular plants [g dry wt ( $g$ dry wt plant) ${ }^{-1}$ ] was measured as discussed above and used to express epiphytic production per unit weight of vascular plant. Bottles were incubated for short time intervals ( 1 to $3 \mathrm{~h}$ ) under ambient light and temperature in either the ponds or in an incubator with continuously circulated estuarine water. Light attenuation, salinity, and temperature of the water column were also measured during each experiment.

Photosynthesis of plants and epiflora was also estimated using uptake of ${ }^{14} \mathrm{C}$-bicarbonate. Whole plants (stem length 40 to $50 \mathrm{~cm}$, rhizome length 10 to $15 \mathrm{~cm}$ ) were carefully removed from sediments and placed with epiphytes intact into clear plexiglass tubes ( 7.5 $\mathrm{cm}$ diameter, $50 \mathrm{~cm}$ long) with the roots of the plants attached to the bottom end of the core. These cores were sealed, and floated vertically in the control pond such that the tip of the shoots were 2 to $3 \mathrm{~cm}$ below water surface and the remainder of the plant extended the length of the core. Carrier-free ${ }^{14} \mathrm{C}$-bicarbonate was injected along the length of the core to achieve an initial activity of $5 \mu \mathrm{Ci} \mathrm{l} l^{-1}$. Plants were incubated for 1 to $2 \mathrm{~h}$ between 1100 and $1300 \mathrm{~h}$.

Following incubation, the control plants were sectioned into $10 \mathrm{~cm}$ lenghts, and the epiphyte colonized
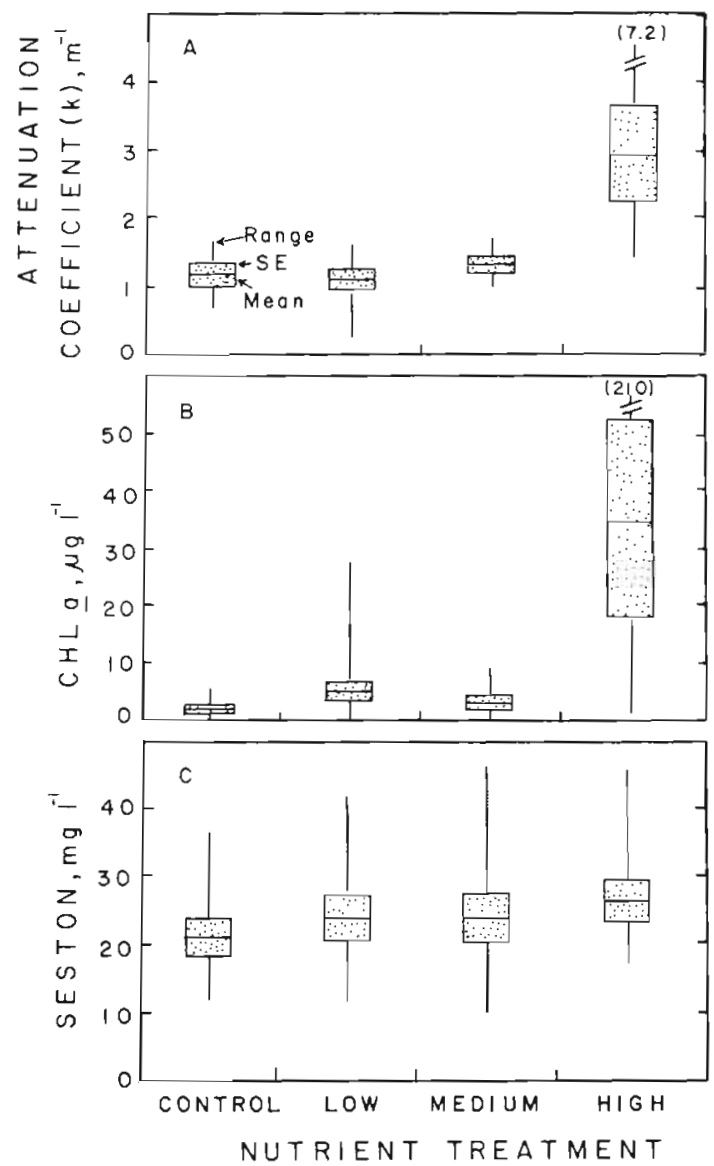

Fig. 2. (A) Photosynthetic active radiation attenuation coefficient $\left(\mathrm{k}, \mathrm{m}^{-1}\right)$, (B) plankton chlorophyll a $\left(\mu \mathrm{g} \mathrm{l}^{-1}\right),(\mathrm{C})$ total seston ( $\mathrm{mg} \mathrm{l}^{-1}$ ) of the water in ponds subjected to 3 nutrient treatments plus controls 
plants were sectioned at $15 \mathrm{~cm}$ from the apical tip into 2 lengths. Epiphytes were removed with a stream of water and a rubber policeman, and the entire contents were filtered (GF/C). Plants and filters were dried to constant weight at $60^{\circ} \mathrm{C}$ and digested in nitric acid according to Lewis et al. (1982). Radioassays were performed with a Packard Tri-Carb 460C liquid scintillation counter standardized with a quench curve. The absolute amount of $\mathrm{CO}_{2}$ incorporation was determined from ${ }^{14} \mathrm{C}$ initial activity and alkalinity measurements (Strickland \& Parsons 1972).

Diel changes of $\mathrm{O}_{2}$ in open waters of the ponds were used to estimate community production and respiration following the approach of Odum \& Hoskin (1958).

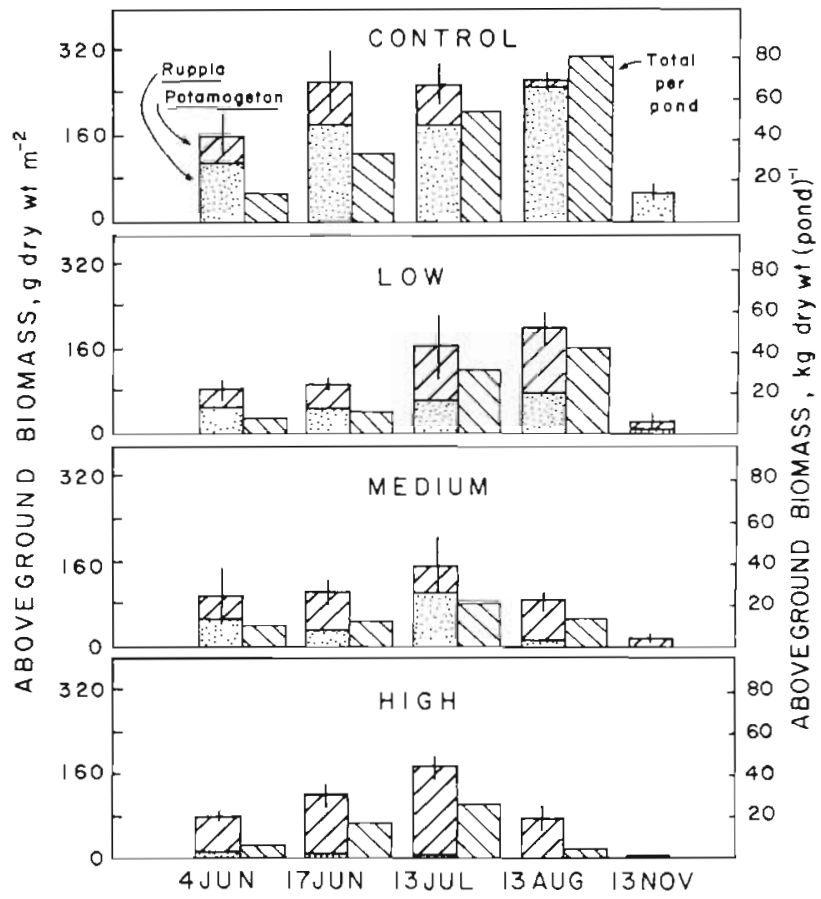

Fig. 3. Aboveground biomass of submersed macrophytes ( $\mathrm{g}$ dry wt) per $\mathrm{m}^{2}$ of vegetated area and per pond subjected to three nutrient treatments plus control. Fertilization began on 18 June 1981. Height of histogram indicates mean value and bar indicates $\pm \mathrm{SE}(\mathrm{n}=12)$ for duplicate ponds

Observations of $\mathrm{O}_{2}$ and temperature were made at the surface and $0.5 \mathrm{~m}$ depth at 3 stations (the end of each sampling pier) in each pond at dawn and at dusk for 2 consecutive days 7 times during the summer. Changes in $\mathrm{O}_{2}$ were corrected for oxygen transfer across the airwater interface by measuring the rate of $\mathrm{O}_{2}$ diffusion from water underlying a floating acrylic dome with an $\mathrm{N}_{2}$-purged atmosphere (Copeland \& Duffer 1964, Kemp \& Boynton 1980). Changes in $\mathrm{O}_{2}$ from dawn to dusk and from dusk to dawn were taken to represent apparent production and night respiration, respectively, of the community.
Other measurements. Attenuation of photosynthetically active radiation (PAR) in each pond was determined with an underwater quantum sensor and meter (LICOR 185A, 192SB). Light attenuation attributable to epiphytic material was determined using a modification of the method of Borum and Wium-Anderson (1980). Here, the reduction in PAR was measured as it passed vertically through a finger bowl $\left(63 \mathrm{~cm}^{2}\right)$ containing different densities of epiphytes removed from Potamogeton perfoliatus leaves and thoroughly mixed in the bowl. Total weight of the epiphytic material was determined by collecting on pre-weighed filters (GF/C) and drying at $60^{\circ} \mathrm{C}$.

Dissolved inorganic nutrients were assayed using a Technicon Autoanalyzer II with standard colorimetric techniques (Environmental Protection Agency 1979). Dissolved oxygen and temperature were measured with polarographic electrodes (Orbisphere Model 2603) and salinity with a Beckman salinometer (Model RS5-3). Chlorophyll a collected on GF/C filters was extracted for $24 \mathrm{~h}$ in $10 \mathrm{ml}$ of a $1: 1$ solution of DMSO and acetone (Shoaf \& Lium 1976), and fluorescence was measured using a Turner Model 111 fluorometer. Concentrations of total suspended solids (seston) were determined gravimetrically according to the method of Banse et al. (1963)

\section{RESULTS}

Concentrations of $\mathrm{NH}_{4}^{+}$and $\mathrm{PO}_{4}^{-3}$ in pond water columns were reduced to control levels $(<2.0 \mu \mathrm{M}$ and $<1.0 \mu \mathrm{M}$, respectively) within $3 \mathrm{~d}$ following treatment for all experimental systems. Nitrate $\left(\mathrm{NO}_{3}^{-}\right)$concentrations also decreased rapidly to levels in control systems $(<1.0 \mu \mathrm{M})$ for all but the high nutrient treatments, where they remained at $30 \%$ initial values after 7 d. Ponds subjected to high nutrient treatments had significantly $(P<0.05)$ elevated concentrations of planktonic chlorophyll a compared to other treatments (Fig. 2). Chlorophyll a above $20 \mu \mathrm{g} \mathrm{I}^{-1}$ was observed only under high dosage, and concentrations generally averaged about 1 to $5 \mu \mathrm{g} \mathrm{l^{-1 }}$ in the other ponds. Mean concentrations of total suspended solids (seston) exhibited a small but statistically insignificant increase with treatment, averaging between 21 and $26 \mathrm{mg} \mathrm{l}^{-1}$ in all ponds. Under most conditions, phytoplankton assemblages were predominantly comprised of diatoms with occasional importance of chlorophytes and dinoflagellates. When chlorophyll a levels were $>20 \mu \mathrm{g}^{-1}$ under high nutrient treatment, plankton communities were virtually monospecific, dominated by a small coccoid chlorophyte. Attenuation of PAR in pond water columns was not statistically different among control $\left(\mathrm{k}=1 \mathrm{~m}^{-1}\right)$, low, and medium nutrient treatments ( $\mathrm{k}=1.1$ to $1.5 \mathrm{~m}^{-1}$ ), but was significantly 
Fig. 4. Epiphytic material expressed as (A) g dry wt (g dry wt plant) ${ }^{-1}$ and (B) $\mathrm{mg}$ chlorophyll a (g dry wt plant) ${ }^{-1}$ on Ruppia maritima and Potamogeton perfoliatus in ponds subjected to 3 nutrient treatments plus controls; fertilization began after June measurements $(\overline{\mathrm{x}} \pm \mathrm{SE})$
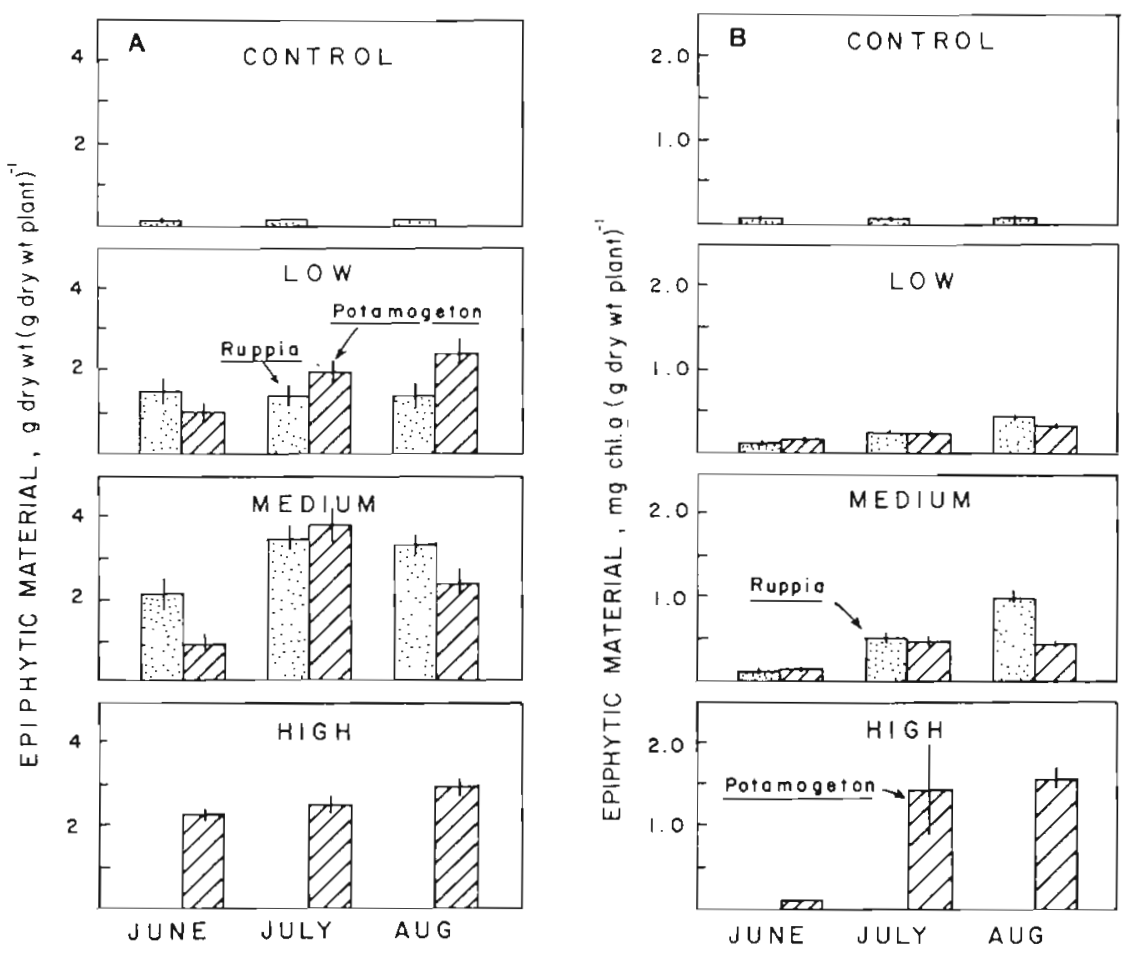

greater under high nutrient treatment, averaging about $4.0 \mathrm{~m}^{-1}$ (with individual readings reaching 8.0 $\mathrm{m}^{-1}$ ) by late August (Fig. 2).

Mean values for plant biomass prior to treatment ranged from about 80 to $120 \mathrm{~g}$ dry wt $\mathrm{m}^{-2}$ for above-

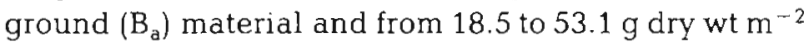
for belowground $\left(B_{b}\right)$, with a consistent $B_{b}: B_{a}$ ratio of about 0.3 for all ponds (Fig. 3). By mid July aboveground biomass had increased to 157 to $237 \mathrm{~g}$ dry wt $\mathrm{m}^{-2}$, and no significant differences $(P<0.05)$ were observed among treatments. One month later, aboveground biomass in the medium and high nutrient ponds had decreased significantly $(P<0.05)$, while plant biomass continued to increase in the low and control ponds (Fig. 3). Over the course of the treatments, there were some shifts in macrophyte species composition. For example, Ruppia maritima was reduced to a subdominant in high dose ponds, with both of the primary species $(R$. maritima and Potamogeton perfoliatus) decreasing in August. Under medium treatment both species were co-dominant until August, when $R$. maritima was virtually eliminated and $P$. perfoliatus actually increased. In general, patterns of total biomass per pond (based on mean values of $\mathrm{g}$ dry wt $\mathrm{m}^{-2}$ in vegetated areas and areal coverage of vegetation) over time and treatment were similar but more pronounced than those evident for biomass in the vegetated areas (Fig. 3).

Total amount (dry wt) of epiphytic material was significantly greater for high nutrient treatment than for low or control and significantly greater for medium dosage ponds compared to controls $(P<0.05)$ (Fig. 4). Dry weight of epiphytes in low dose ponds exhibited steadily increasing levels throughout the summer, while under control conditions epiphytic weights remained at $<5 \%$ of those in other ponds. There was no distinct difference in accumulation of epiphytes on

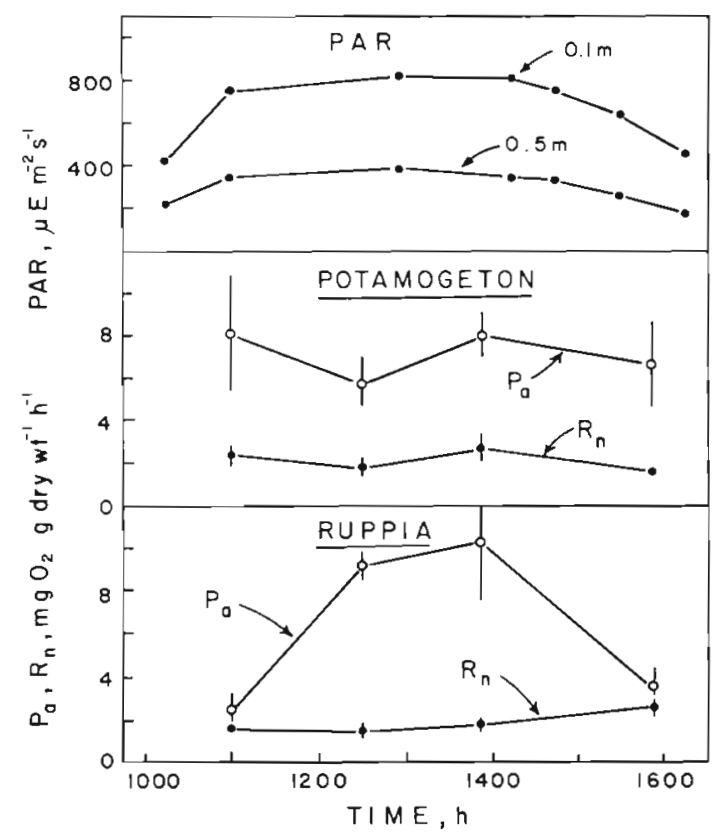

Fig. 5. Ruppia maritima and Potamogeton perfoliatus. Photosynthetic active radiation $\left(\mu \mathrm{E} \mathrm{m}^{-2} \mathrm{~s}^{-1}\right)$ at 0.1 and $0.5 \mathrm{~m}$ depth from midmorning to midafternoon, along with measurements of apparent production $\left(\mathrm{P}_{\mathrm{a}}\right)$ and dark respiration $\left(\mathrm{R}_{\mathrm{n}}\right)(\overline{\mathrm{x}} \pm \mathrm{SE})$ 


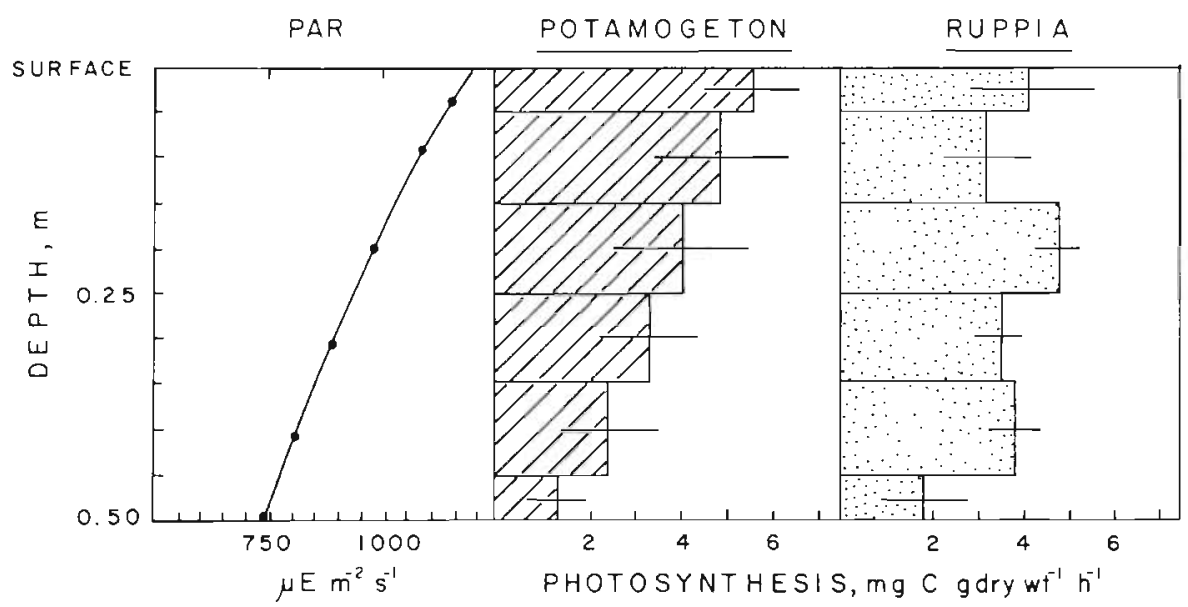

Fig. 6. Potamogeton perfoliatus and Ruppia maritima. Net ${ }^{14} \mathrm{C}$ photosynthesis (mgC g dry wt ${ }^{-1}$ $\mathrm{h}^{-1}$ ) with depth along the length of plants cleaned of epiphytic material $(\bar{x} \pm S E)$. Included is the amount of photosynthetic active radiation $\left(\mu \mathrm{E} \mathrm{m}^{-2} \mathrm{~s}^{-1}\right)$ from 0.1 to $0.5 \mathrm{~m}$ depth measured in an unvegetated area

Ruppia maritima versus Potamogeton perfoliatus in the low and medium dosed ponds, and both plants were important to total biomass (Fig. 3 \& 4). Overall, epiphytic chlorophyll $a$ was more responsive to nutrient treatment compared to epiphytic dry weight (Fig. 4). A dramatic increase in epiphytic algae was evident for $P$. perfoliatus under high treatment; for example chlorophyll a levels increased from 0.07 to $1.59 \mathrm{mg} \mathrm{(g}$ dry wt plant) ${ }^{-1}$ between June and July. The dominant species of epiphytic algae occurring on both submersed plants included Nitzschia closterium and $N$. paradora, other pennate diatoms (e.g. Cocconeis, Navicula, Amphora, Amphipora, Pleurosigma, Gyrosigma), Melosira nummuloides and a few dinoflagellates (dominated by Peridiniumn).
The 2 dominant macrophytes, Potamogeton perfoliatus and Ruppia maritima, had distinctly different diurnal and depth-related patterns of production. Apparent $\mathrm{O}_{2}$ production $\left(\mathrm{P}_{\mathrm{a}}\right)$ and dark respiration $\left(\mathrm{R}_{\mathrm{n}}\right)$ for $P$. perfoliatus were relatively constant from 1000 to $1630 \mathrm{~h}$ on a cloudless day in mid June, with a $P_{\mathrm{a}}: R_{\mathrm{n}}$ ratio of about 1.8 (Fig. 5). In contrast, $\mathrm{P}_{\mathrm{a}}$ of $R$. maritima was nearly 4 times greater at midday than in morning and afternoon; however, $R_{n}$ was relatively constant during the day so that $P_{a}: R_{n}$ ranged from 1.8 in the morning to 5.7 at midday. Net production along plant stems decreased significantly with depth along the length of $P$. perfoliatus, but not so for $R$. maritima (Fig. 6). Similarly, ${ }^{14} \mathrm{C}$ incorporation and $\mathrm{O}_{2}$ production for $P$. perfoliatus for all nutrient treatments were consistently

Table 1. Potamogeton perfoliatus. Oxygen production, respiration, and production: respiration ratios of apical (0 to $15 \mathrm{~cm})$ and basal $(15$ to $45 \mathrm{~cm})$ sections from experimental ponds fertilized at 2 levels of treatment $\left(\mathrm{mgO}_{2}\left(\mathrm{~g}\right.\right.$ dry wt plant) $\left.{ }^{-1} \mathrm{~h}^{-1}\right)$. Also included is epiphytic mass on experimental $P$. perfoliatus leaves [ $\mathrm{g}$ dry $\mathrm{wt}$ ( $\mathrm{g}$ dry $\mathrm{wt}$ plant $)^{-1}$ ]

\begin{tabular}{|c|c|c|c|c|c|c|c|c|c|}
\hline \multirow[t]{3}{*}{ Date } & \multirow[t]{3}{*}{ Treatment } & \multicolumn{2}{|c|}{ Epiphytic weight } & \multicolumn{6}{|c|}{ Metabolism } \\
\hline & & \multirow{2}{*}{$\begin{array}{l}\text { Apical } \\
\text { section }\end{array}$} & \multirow{2}{*}{$\begin{array}{c}\text { Basal } \\
\text { section }\end{array}$} & \multicolumn{3}{|c|}{ Apical section } & \multicolumn{3}{|c|}{ Basal section } \\
\hline & & & & Plant & Epiphyte & Total & Plant & Epiphyte & Total \\
\hline \multicolumn{10}{|c|}{ Photosynthesis } \\
\hline \multirow{2}{*}{$15 \mathrm{Jul}$} & Low & 0.74 & 1.03 & 9.20 & 2.09 & 11.29 & 4.80 & 2.06 & 6.86 \\
\hline & High & 1.26 & 2.87 & 2.87 & 3.72 & 6.59 & 2.18 & 0.61 & 2.79 \\
\hline \multirow{2}{*}{5 Aug } & Low & 0.67 & 0.89 & 9.79 & 2.77 & 12.56 & 6.10 & 1.08 & 7.18 \\
\hline & High & 2.11 & 1.66 & 0 & 8.95 & 8.95 & 0 & 5.49 & 5.49 \\
\hline \multicolumn{10}{|c|}{ Respiration } \\
\hline \multirow[t]{2}{*}{$15 \mathrm{Jul}$} & Low & 0.74 & 1.03 & 0.30 & 0.90 & 1.20 & 0.90 & 0.79 & 1.69 \\
\hline & High & 1.26 & 2.87 & 1.09 & 0.71 & 1.80 & 6.03 & 1.11 & 7.14 \\
\hline \multirow[t]{2}{*}{$5 \mathrm{Aug}$} & Low & 0.67 & 0.89 & 2.45 & 0.77 & 3.22 & 1.78 & 0.60 & 2.38 \\
\hline & High & 2.11 & 1.66 & 0.25 & 5.57 & 5.82 & 1.65 & 2.61 & 4.26 \\
\hline \multicolumn{10}{|c|}{$\mathbf{P}_{\mathrm{a}}: \mathbf{R}_{\mathrm{n}}$ Ratio } \\
\hline \multirow[t]{2}{*}{$15 \mathrm{Jul}$} & Low & 0.74 & 1.03 & 30.7 & ND & 9.4 & 5.3 & ND & 3.4 \\
\hline & High & 1.26 & 2.87 & 2.6 & ND & 3.7 & 0.1 & $\mathrm{ND}$ & 0.9 \\
\hline \multirow[t]{2}{*}{$5 \mathrm{Aug}$} & Low & 0.67 & 0.89 & 4.0 & ND & 3.9 & 3.4 & ND & 3.0 \\
\hline & High & 2.11 & 1.66 & 0 & ND & 1.5 & 0 & ND & 1.2 \\
\hline
\end{tabular}


Table 2. Potamogeton perfoliatus and Ruppia maritima. Photosynthesis (based on ${ }^{14} \mathrm{C}$-bicarbonate uptake) of the apical (0 to 15

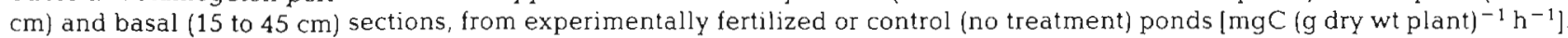
Also included is epiphytic mass on experimental vascular plant leaves [ $\mathrm{g}$ dry $w t\left(\mathrm{~g} d r y\right.$ wt plant) ${ }^{-1}$ ]. Rates were measured on 21 September 1982

\begin{tabular}{|c|c|c|c|c|c|}
\hline \multirow[t]{2}{*}{ Species } & \multirow[t]{2}{*}{ Treatment } & \multirow[t]{2}{*}{ Weight } & \multicolumn{3}{|c|}{ Photosynthesis } \\
\hline & & & Plant & Epiphyte & Total \\
\hline \multicolumn{6}{|c|}{ Apical section } \\
\hline \multirow[t]{3}{*}{ P. perfoliatus } & Control & 0.29 & 5.09 & 0.04 & 5.13 \\
\hline & Medium & 2.01 & 5.14 & 2.39 & 7.53 \\
\hline & High & 5.04 & 3.07 & 4.05 & 7.12 \\
\hline \multirow{2}{*}{ R. maritima } & Control & ND & 3.62 & ND & ND \\
\hline & Medium & 0.49 & 2.56 & 0.31 & 2.87 \\
\hline \multicolumn{6}{|c|}{ Basal section } \\
\hline \multirow[t]{3}{*}{ P. perfoliatus } & Control & 0.27 & 2.32 & 0.02 & 2.34 \\
\hline & Medium & 1.14 & 2.40 & 1.24 & 3.64 \\
\hline & High & 3.65 & 1.46 & 2.57 & 4.03 \\
\hline \multirow[t]{2}{*}{ R. maritima } & Control & ND & 3.14 & ND & ND \\
\hline & Medium & 0.39 & 0.73 & 0.29 & 1.02 \\
\hline
\end{tabular}

greater for apical than for basal sections of the plant (Tables 1 \& 2).

Apparent $\mathrm{O}_{2}$ production of Potamogeton perfoliatus was markedly inhibited under high nutrient treatment compared to rates for plants from low nutrient ponds
(Table 1). During June and July, $\mathrm{P}_{\mathrm{a}}$ for apical sections of plants from high treatment were only half those for the low treatment, and by August no $\mathrm{P}_{\mathrm{a}}$ was measureable in either the apical or basal sections of plants from the highly fertilized ponds. Whereas vascular plants

Table 3. Mean $(\bar{X})$ and standard error of the mean $\left(S_{\bar{x}}\right)$ for apparent production $\left(P_{a}\right)$ and respiration $\left(R_{n}\right)\left(g O_{2} m^{-3} d^{-1}\right)$, and $P_{a}$ to $R_{n}$ ratios of the pond communities under control $(C)$, low (L), medium (M) and high (H) nutrient treatment. Means with same superscript letters are not significantly different $(P<0.05)$ for a specific date. Nutrient treatments began on 19 June 1981 and ended on 4 August 1981

\begin{tabular}{|c|c|c|c|c|c|c|c|c|c|c|c|c|c|}
\hline \multirow[t]{2}{*}{ Date } & & \multicolumn{4}{|c|}{ Apparent production $\left(\mathrm{P}_{\mathrm{a}}\right)$} & \multicolumn{4}{|c|}{ Night respiration $\left(R_{n}\right)$} & \multicolumn{4}{|c|}{ Ratios, $\mathrm{P}_{\mathrm{a}}: \mathrm{R}_{\mathrm{n}}$} \\
\hline & & C & L & $\mathrm{M}$ & $\mathrm{H}$ & C & L & $M$ & $\mathrm{H}$ & C & L & $M$ & $\mathrm{H}$ \\
\hline 15 Jun 1981 & $\begin{array}{c}\bar{X} \\
\left(S_{\bar{x}}\right)\end{array}$ & $\begin{array}{c}6.10^{\mathrm{a}} \\
(0.63)\end{array}$ & $\begin{array}{r}5.53^{\circ} \\
(0.62) \\
(\mathrm{n}=\end{array}$ & $\begin{aligned} & 5.40^{\mathrm{a}} \\
&(0.79) \\
&=4)\end{aligned}$ & $\begin{array}{c}4.67^{\circ} \\
(0.77)\end{array}$ & $\begin{array}{c}3.15^{\mathrm{a}} \\
(0.24)\end{array}$ & $\begin{array}{r}3.59^{\mathrm{a}} \\
(0.22) \\
(\mathrm{n}\end{array}$ & $\begin{aligned} & 4.08^{\circ} \\
& (0.16) \\
= & 6)\end{aligned}$ & $\begin{array}{c}3.75^{\mathrm{a}} \\
(0.37)\end{array}$ & 1.9 & 1.5 & 1.3 & 1.2 \\
\hline 23 Jun 1981 & $\begin{array}{c}\bar{X} \\
\left(S_{\bar{x}}\right)\end{array}$ & $\begin{array}{c}5.77^{a} \\
(0.66)\end{array}$ & $\begin{array}{c}5.76^{\bar{a}} \\
(0.24) \\
(\mathrm{n}=\end{array}$ & $\begin{aligned} & 5.99^{a} \\
& (0.24) \\
= & 12)\end{aligned}$ & $\begin{array}{c}6.12^{\mathrm{a}} \\
(0.43)\end{array}$ & $\begin{array}{c}3.03^{a} \\
(0.44)\end{array}$ & $\begin{array}{c}3.16^{\mathrm{a}} \\
(0.14) \\
(\mathrm{n})\end{array}$ & $\begin{array}{l}3.51^{\mathrm{a}} \\
(0.22) \\
=6)\end{array}$ & $\begin{array}{l}4.18^{a} \\
(0.68)\end{array}$ & 1.9 & 1.8 & 1.7 & 1.5 \\
\hline 16 Jul 1981 & $\begin{array}{c}\bar{X} \\
\left(S_{\bar{x}}\right)\end{array}$ & $\begin{array}{c}5.70^{a} \\
(0.75)\end{array}$ & $\begin{array}{c}5.48^{\mathrm{a}} \\
(0.83) \\
\quad(\mathrm{n}=\end{array}$ & $\begin{aligned} & 6.74^{\mathrm{a}} \\
& (1.27) \\
= & 12)\end{aligned}$ & $\begin{array}{c}6.87^{a} \\
(0.93)\end{array}$ & $\begin{array}{c}4.46^{c} \\
(0.22)\end{array}$ & $\begin{array}{c}4.81^{b c} \\
(0.25) \\
(n=\end{array}$ & $\begin{aligned} & 5.35^{\mathrm{b}} \\
&(0.17) \\
&=6)\end{aligned}$ & $\begin{array}{l}6.54^{\mathrm{a}} \\
(0.23)\end{array}$ & 1.3 & 1.1 & 1.1 & 1.1 \\
\hline 23 Jul 1981 & $\begin{array}{c}\bar{X} \\
\left(S_{\bar{x}}\right)\end{array}$ & $\begin{array}{l}8.16^{a} \\
(0.55)\end{array}$ & $\begin{array}{c}5.92^{\mathrm{b}} \\
(0.30)\end{array}$ & $\begin{array}{l}6.44^{\mathrm{b}} \\
(0.23)\end{array}$ & $\begin{array}{c}9.30^{\mathrm{a}} \\
(0.30)\end{array}$ & $\begin{array}{l}5.86^{b} \\
(0.37)\end{array}$ & $\begin{array}{c}5.45^{\mathrm{b}} \\
(0.32)\end{array}$ & $\begin{array}{c}6.10^{b} \\
(0.11)\end{array}$ & $\begin{array}{c}7.93^{\mathrm{a}} \\
(0.36)\end{array}$ & 1.4 & 1.1 & 1.1 & 1.2 \\
\hline & & & $(n=$ & $=6)$ & & & $(\mathrm{n}=$ & $=6)$ & & & & & \\
\hline $30 \mathrm{Jul} 1981$ & $\begin{array}{c}\bar{X} \\
\left(\mathrm{~S}_{\overline{\mathrm{x}}}\right)\end{array}$ & $\begin{array}{c}8.23^{a} \\
(0.37)\end{array}$ & $\begin{array}{c}7.60^{\circ} \\
(0.32) \\
(\mathrm{n}=\end{array}$ & $\begin{aligned} & 9.92^{\mathrm{a}} \\
&(0.52) \\
&=12)\end{aligned}$ & $\begin{array}{l}10.37^{a} \\
(1.68)\end{array}$ & $\begin{array}{c}4.85^{b} \\
(0.33)\end{array}$ & $\begin{array}{r}3.95^{b} \\
(0.29) \\
(\mathrm{n}=\end{array}$ & $\begin{aligned} & 5.20^{\mathrm{b}} \\
&(0.58) \\
&= 6 \mathrm{~J}\end{aligned}$ & $\begin{array}{c}6.99^{\mathrm{a}} \\
(0.52)\end{array}$ & 1.7 & 1.9 & 1.9 & 1.5 \\
\hline 10 Aug 1981 & $\begin{array}{c}\bar{X} \\
\left(S_{\bar{x}}\right)\end{array}$ & $\begin{array}{l}6.21^{b} \\
(0.47)\end{array}$ & $\begin{array}{c}3.90^{\mathrm{c}} \\
(0.54) \\
(\mathrm{n}=\end{array}$ & $\begin{array}{c}9.70^{\mathrm{a}} \\
(0.58) \\
= \\
8)\end{array}$ & $\begin{array}{c}1.70^{\mathrm{d}} \\
(0.26)\end{array}$ & $\begin{array}{c}2.48^{\mathrm{a}} \\
(0.33)\end{array}$ & $\begin{array}{c}2.14^{\mathrm{a}} \\
(0.70) \\
(\mathrm{n}\end{array}$ & $\begin{aligned} & 3.77^{a} \\
&(0.24) \\
&=6]\end{aligned}$ & $\begin{array}{c}3.05^{\mathrm{a}} \\
(0.66)\end{array}$ & 2.5 & 1.8 & 2.3 & 0.6 \\
\hline
\end{tabular}



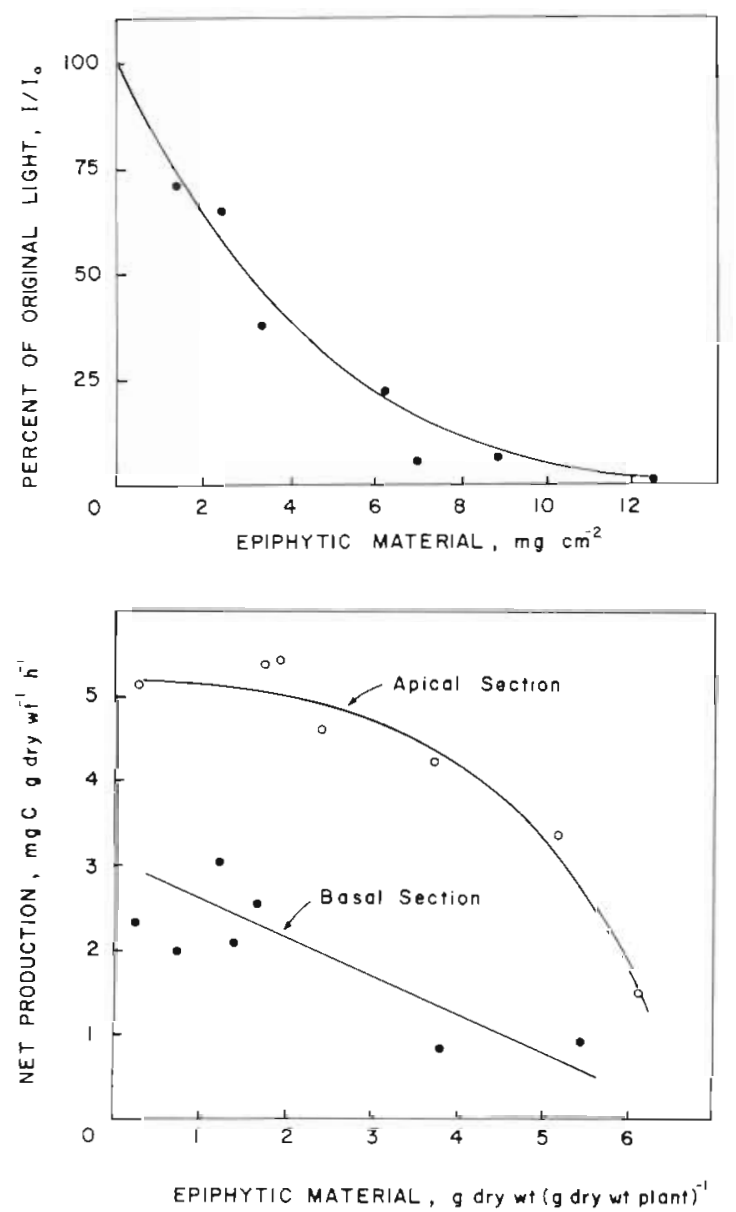

Fig. 7. Upper: Percent of original photosynthetically active radiation passing through different densities of epiphytic material (expressed as mg dry wt $\mathrm{cm}^{-2}$ ). Lower: ${ }^{14} \mathrm{C}$ incorporation by Potamogeton perfoliatus for apical $(0$ to $15 \mathrm{~cm}$ from tip) and basal (15 to $45 \mathrm{~cm}$ from tip) sections colonized with different concentrations of epiphytic material [ $g$ dry wt (g dry wt plant) ${ }^{-1}$

from low nutrient treatment contributed $>75 \%$ of the combined (plant plus epiphyte) $\mathrm{P}_{\mathrm{a}}$, those from the high dosed ponds comprised only 0 to $44 \%$ of the combined $\mathrm{P}_{\mathrm{a}}$. Rates of plant respiration were directly related to nutrient treatment, with plants under high treatment exhibiting 1.5 to 2.5 greater rates than those from low treatment (Table 1). Thus, ratios of $P_{a}$ to $R_{n}$ (Table 1) were much lower $(0.1$ to 2.6$)$ for the heavily fertilized plants than for those from low nutrient treatments $(3.4$ to 30.7$)$. Dry weights of epiphytic material in these experiments were similar to those observed in the regular samplings (c.f. Tables $1 \& 2$; Fig. 4).

Rates of ${ }^{14} \mathrm{C}$-bicarbonate incorporation for both Potamogeton perfoliatus and Ruppia maritima exhibited nutrient treatment effects similar to those observed for $\mathrm{O}_{2}$ metabolism (Table 2). Photosynthetic incorporation of ${ }^{14} \mathrm{C}$ for $P$. perfoliatus was significantly higher $(P<0.05)$ in control and medium nutrient treat- ments than for plants under high nutrients. ${ }^{14} \mathrm{C}$ incorporation of $R$. maritima was significantly lower in the medium nutrient pond compared to controls (Table 2).

There was a strong inverse relationship between the mass of epiphytic material on apical and basal sections of Potamogeton perfoliatus and ${ }^{14} \mathrm{C}$ incorporation by the vascular plant (Fig. 7). At epiphytic concentrations $<2.0 \mathrm{~g}$ dry wt (g dry wt plant) ${ }^{-1}$, production of neither apical nor basal sections of the vascular plant appeared to have been affected. At densities of epiphytic material $>2 \mathrm{~g}$ dry wt ( $\mathrm{g}$ dry wt plant) ${ }^{-1}$, there was a gradual reduction in net production of growing tips with increasing epiphytes to about $6 \mathrm{~g}$ dry wt ( $\mathrm{g}$ dry wt plant) ${ }^{-1}$. A similar, but less pronounced trend was observed for basal sections, and at the upper levels of epiphytic material, net production for apical and basal sections tended to converge. Comparable negative effects of epiphytic dry weight on vascular plant production are evident also in the $\mathrm{O}_{2}$ experiments (Table 1).

Apparent $\mathrm{O}_{2}$ production of integrated communities in both control and low-nutrient ponds increased through the last week of July (Table 3). During the same period, $\mathrm{P}_{\mathrm{a}}$ in medium and high nutrient dosed ponds also increased, being considerably higher (significantly so on 23 July) than for control and low treatments. An increase in $\mathrm{P}_{\mathrm{a}}$ of about $4.5 \mathrm{~g} \mathrm{O}_{2} \mathrm{~m}^{-3} \mathrm{~d}^{-1}$ above pretreatment values was evident for both medium and high treatments ( 1 wk later). This relative increase in $\mathrm{P}_{\mathrm{a}}$ (compared to pretreatment) was more than double that observed for either control or low nutrient treatments (Table 3). Following a production maximum occurring in late July, community $P_{a}$ returned in August to near pretreatment levels in control and low dose systems, while decreasing by a factor of 6 under high treatment. Only the medium treatment ponds maintained $\mathrm{P}_{\mathrm{a}}$ in August similar to rates in July. In general, variances for night respiration $\left(R_{n}\right)$ measurements in pond communities were lower than for $\mathrm{P}_{\mathrm{a}}$ so that differences among treatments were clearer for $R_{n}$. Throughout July, $R_{n}$ was significantly greater for high treatment communities than for all others, while medium treated ponds also had statistically elevated $R_{n}$ compared to control in mid-July (Table 3 ). Consequently, the ratio of $P_{a}: R_{n}$ was significantly reduced under high nutrient treatment relative to controls over the course of the study (Table 3 ).

\section{DISCUSSION}

\section{Algal response to nutrient enrichment}

The generally insignificant response of phytoplankton to low and medium nutrient treatments (Fig. 2) may represent the inability of our sampling scheme to 
detect ephemeral blooms (with 1 to 3 measurements $\mathrm{wk}^{-1}$ ). We observed increases in chlorophyll $a$ of 1 to 2 orders of magnitude for high nutrient treatments within 1 to $2 \mathrm{~d}$, suggesting the high temporal variability of these populations. Other investigators have also reported widely fluctuating chlorophyll a levels in response to nutrient additions (Edmondson 1955, O'Brien \& DeNoyelles 1974) and have attributed this erratic behavior to such factors as $\mathrm{pH}$ (carbon limitation) and grazing. An alternative explanation may be a relatively inferior ability of phytoplankton to compete with submersed grasses and their epiphytes for limited nutrients in these shallow pond systems.

A number of recent fertilization studies have indicated that growth of epiphytic algae may be more important than phytoplankton in terms of relative effects on submersed vascular plants (Moss 1976, Phillips et al. 1978, Cattaneo \& Kalff 1980, Harlin \& Thorne-Miller 1981, Sand-Jensen \& Søndergaard 1981). In our experiments, epiphytes exhibited a response to fertilization different from that of phytoplankton. All fertilized treatments (low, medium, high) had elevated levels of epiphytic material compared to controls, whereas phytoplankton had elevated levels only under the most extreme nutrient addition. Levels of epiphytic material in fertilized ponds were similar to those reported previously for isolated, nutrient rich waters of Chesapeake Bay (Staver et al. 1981) and upper Hudson River estuary (Menzie 1979), while con trol levels were comparable to those at relatively open, well-flushed sites in Chesapeake Bay (Staver et al. 1981).

\section{PAR attenuation by algal biomass}

Nutrient-stimulated algal growth can effect a loss of submersed vascular plant production through several mechanisms, including attenuance of PAR. In our experiment, coefficients for diffuse downwelling attenuation of PAR $(\mathrm{k})$ exhibited a weak but statistically significant correlation $(\mathrm{k}=0.0396(\mathrm{~S})+0.39$, $\mathrm{r}^{2}=0.32, \mathrm{n}=15$ ) with total seston (S). The slope of this relation is about twice that which was determined experimentally $(0.0174)$ for resuspended (predominantly inorganic) bottom sediments (Kemp et al. 1981). This difference is probably attributable to the effects of planktonic material in the pond seston. Overall, the relation between $\mathrm{k}$ and planktonic chlorophyll a (C) was variable, particularly at low pigment levels where other materials dominated the seston. However, if we consider only the few instances $(n=8)$ where algal cells comprised a major fraction of seston $(>10 \%)$, a very strong correlation occurs $[\mathrm{k}=0.0146(\mathrm{C})+0.94$, $\left.\mathrm{r}^{2}=0.95\right]$. This slope is intermediate between those obtained for pure algal cultures (e.g. Bannister 1974) and those from field correlations in coastal waters (e.g. Riley 1956, Scott 1978).

Epiphytic material also reflects and absorbs PAR before reaching the leaf surfaces of vascular plants. We obtained a strong negative exponential relation ( $\mathrm{n} \mathrm{I} / \mathrm{I}_{0}=0.32-0.42 \mathrm{E}, \mathrm{r}^{2}=0.96, \mathrm{n}=7$ ) between PAR attenuance through a horizontal plane $\left(\mathrm{I} / \mathrm{I}_{0}\right)$ and the dry weight of epiphytic material, E (Fig. 7). This slope is very similar to the relation obtained above for seston (for a $1.0 \mathrm{~m}$ water column), suggesting that the attenuance properties (per unit weight) of seston and epiphytes in this study were comparable. A few previous studies have considered this relation between epiphytic material and light attenuance (Phillips et al. 1978, Sand-Jensen \& Søndergaard 1981, Bulthuis \& Woelkerling 1983, Sand-Jensen \& Borum 1983). In general, PAR attenuance patterns reported in these papers appear to be similar to those obtained here; however differences in units of measure make quantitative comparisons difficult (Staver 1984).

\section{Effects of epiphytes on submersed vascular plants}

The development of epiphytic communities on the leaves of vascular plants may reduce net production through several mechanisms other than PAR attenuation, including the reduction of diffusive transport of inorganic carbon, nitrogen and phosphorus. Furthermore, the relation between light reduction and loss of photosynthesis is only linear at PAR levels below the light-saturated level of photosynthesis $\left(\mathrm{P}_{\max }\right)$. Thus, it is important to consider directly the effects of epiphytic material on photosynthesis of submersed plants.

Reductions in photosynthesis (both $\mathrm{O}_{2}$ production and ${ }^{14} \mathrm{C}$ incorporation) of submersed plants were observed to correspond with increased epiphytic material associated with nutrient enrichment. We estimated PAR available to plants in the ${ }^{14} \mathrm{C}$ experiments by using 2 relationships developed in this study: (1) epiphytic weight per area versus PAR reduction (discussed above); and (2) epiphytic weight per unit leaf area $\left(\mathrm{A}, \mathrm{cm}^{2}\right)$ versus weight per $\mathrm{g}$ dry wt of leaves (W) for apical sections of Potamogeton perfoliatus $[\mathrm{A}=1.30(\mathrm{~W})-9.14]$. Here, mean PAR flux to apical sections not colonized by epiphytes was about $1100 \mu \mathrm{E}$ $\mathrm{m}^{-2} \mathrm{~s}^{-1}$ (Fig. 6), and apical sections with the heaviest epiphytic colonization [6.13 $\mathrm{g}$ dry wt ( $\mathrm{g}$ dry wt plant) ${ }^{-1}$ ] received only about $57 \mu \mathrm{E} \mathrm{m}^{-2} \mathrm{~s}^{-1}$. Based on these calculated values of PAR available to $P$. perfoliatus after attenuation by epiphytes, a relationship between plant production and available light was developed (Fig. 8). This derived relationship is almost identical to photosynthesis-irradiance (P-I) curves obtained by direct measurements for the same species, with an 


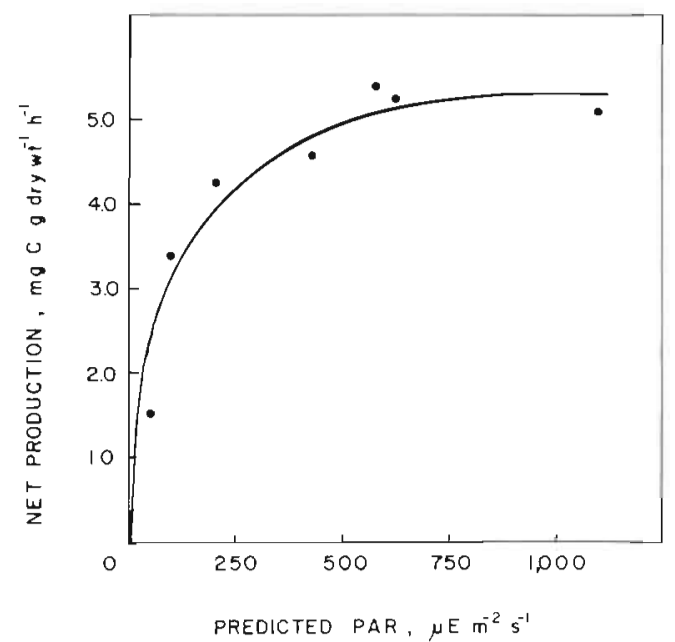

Fig. 8. Potamogeton perfoliatus. Relations between ${ }^{14} \mathrm{C}$ uptake and photosynthetically active radiation (PAR) for apical sections ( 0 to $15 \mathrm{~cm}$ from tip), based on calculated light attenuation associated with specific levels of epiphytic material

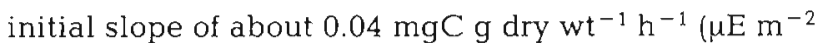
$\left.\mathrm{s}^{-1}\right)^{-1}$ and $\mathrm{P}_{\max }$ at $5.2 \mathrm{mgC} \mathrm{g}$ dry $\mathrm{wt}^{-1} \mathrm{~h}^{-1}$ (Goldsborough 1983).

Other investigators have considered the effects of epiphytic colonization on production of submersed plants, but only at a single level of epiphytes. SandJensen (1977) used P-I curves to show that Zostera marina with epiphytes exhibited consistently lower production than relatively clean plants. In that study, inhibition was evident even at $1200 \mu \mathrm{E} \mathrm{m}^{-2} \mathrm{~s}^{-1}$, and this, coupled with additional experiments, suggested that reduced $\mathrm{CO}_{2}$ uptake by epiphyte colonized $Z$. marina may have been important as well (Sand-Jensen 1977). Similar experiments by Penhale \& Smith (1977) indicated little epiphytic effect on $Z$. marina photosynthesis below $800 \mu \mathrm{E} \mathrm{m}^{-2} \mathrm{~s}^{-1}$. In contrast, all of the observed inhibition of photosynthesis in the present study (Fig. 7 ; Table 1) could be explained as a response to reduction in light (e.g. Fig. 8).

More recently, Sand-Jensen \& Søndergaard (1981) have argued that light attenuation associated with epiphytic growth exerts a far greater impact on submersed vascular plants than that by phytoplankton in Danish lakes subjected to different degrees of fertilization. This is probably the case for these lakes where phytoplankton pigments were $<10 \mu \mathrm{gl}^{-1}$ and water column attenuation coefficients were generally $<1.0$ $\mathrm{m}^{-1}$. In many estuarine systems such as upper Chesapeake Bay, however, attenuation coefficients of 1 to $4 \mathrm{~m}^{-1}$ are common, and chlorophyll a typically ranges from 5 to $30 \mathrm{\mu g} \mathrm{l}^{-1}$ (Wetzel \& Penhale 1983, Ward et al. 1984). Most of the water-column attenuation in such estuaries is probably due to suspended sediments, although plankton are also important.
In the present fertilization experiments, both plankton and epiphytes contributed substantially to PAR attenuation, particularly in ponds under high nutrient treatment. For example, with a typical summer PAR of $1200 \mu \mathrm{E} \mathrm{m}^{-2} \mathrm{~s}^{-1}$ incident at the water surface and a water column $\mathrm{k}=3.0 \mathrm{~m}^{-1}$ (e.g. Fig. 2), there would be 570,270 and $60 \mu \mathrm{E} \mathrm{m}^{-2} \mathrm{~s}^{-1}$ available at depths of 0.25 , 0.5 and $1.0 \mathrm{~m}$ (sediment surface), respectively. In general, values of light compensation levels for Potamogeton perfoliatus are about 50 to $100 \mu \mathrm{E} \mathrm{m}^{-2} \mathrm{~s}^{-1}$ (Goldsborough 1983), so that net production may not be possible at the sediment surface. With epiphytic colonization at $4.0 \mathrm{~g} \mathrm{dry} \mathrm{wt} \mathrm{(g} \mathrm{dry} \mathrm{wt} \mathrm{plant)}{ }^{-1}$ (Fig. 4), only about 90 and $40 \mu \mathrm{E} \mathrm{m}^{-2} \mathrm{~s}^{-1}$ would be available for leaves at depths of $0.25 \mathrm{~m}$ and $0.5 \mathrm{~m}$, respectively. Thus, unless these vascular plants can adapt physiologically or morphologically to such rigorous light regimes, they cannot exist under the combined stress of water column turbidity plus epiphytic colonization.

\section{Responses of plant populations and associated communities}

Nutrient loading rates $\geq 60 \mu \mathrm{mol} \mathrm{N} \mathrm{^{-1 }} \mathrm{wk}^{-1}(6 \mu \mathrm{mol}$ $\mathrm{P}^{-1} \mathrm{wk}^{-1}$ ) resulted in a significant decline in vascular plant biomass in our experimental ponds. Although few previous fertilization studies have examined estuarine macrophyte communities, several investigations with freshwater systems have reported findings similar to ours (Mulligan \& Baranowski 1969, Ryan et al. 1972, Moss 1976, Mulligan et al. 1976, Phillips et al. 1978, Howard-Williams 1981). In all of these studies,

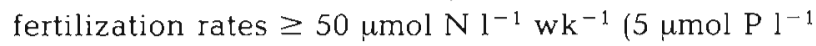
$\mathrm{wk}^{-1}$ ) resulted in significant reductions in vascular plant abundance within 6 to $10 \mathrm{wk}$. At $300 \mu \mathrm{mol} \mathrm{N}^{-1}$

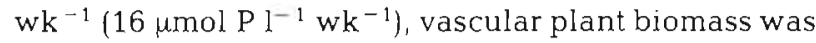
completely eliminated in 5 of 6 experimental ponds (Mulligan et al. 1976).

Of the 2 major species in our experimental ponds, Ruppia maritima dominated the control and medium treatment ponds, while Potamogeton perfoliatus dominated low and high dose systems through mid July. Yet even with these species differences, there was no significant difference in biomass among the 3 treatments and control ponds in July (after 3 experimental fertilizations). The decline of total plant biomass in medium nutrient ponds between July and August involved a virtual elimination of $R$. maritima with a small increase in $P$. perfoliatus, whereas the parallel loss of aboveground biomass under high fertilization occurred at the expense of both species. During the same period, the relative contributions of $R$. maritima and $P$. perfoliatus to total plant biomass were constant in the low nutrient treatment. By mid August, P. perfoliatus domi- 
nated in all treated ponds, while control ponds were vegetated almost exclusively with $R$. maritima.

Measurements of ${ }^{14} \mathrm{C}$ uptake by individual plants also showed that Potamogeton perfoliatus was less affected than Ruppia maritima by epiphytic algal growth (and attenuation of PAR) associated with fertilization. Vertically integrated net production for $R$. maritima from medium treatment ponds was only $48 \%$ of that for plants from the controls, whereas rates of ${ }^{14} \mathrm{C}$ incorporation by $P$. perfoliatus were actually greater from medium nutrient treatment compared to controls (Table 2). Diurnal trends in $\mathrm{P}_{\mathrm{a}}$ for $P$. perfoliatus and $R$. maritima suggested that the latter species was more responsive to light changes than was $P$. perfoliatus (Fig. 5). The relatively high values of $P_{a}$ for $P$. perfoliatus at the lower PAR in morning and afternoon may reflect the ability of this species to rapidly alter its quantum efficiency (Goldsborough 1983). The strong inverse relationship between depth and $P$. perfoliatus production (Fig. 6) suggests that this species can exploit the exponentially increasing light towards the water surface and the reduced epiphytic colonization near the plant's young, actively growing apical section (e.g. Staver 1984).

There are some parallels in time-course trends of total plant biomass (above-ground) and apparent production of the integrated experimental communities. Most notable is the fact that in August when plant biomass decreased under high nutrient dosage (Fig. 3), a similar decrease in $\mathrm{P}_{\mathrm{a}}$ was also observed for these communities (Table 3). On the other hand, the decrease in vascular plants for medium treated ponds in August was not accompanied by a reduction in community $\mathrm{P}_{\mathrm{a}}$. In general, levels of community $\mathrm{P}_{\mathrm{a}}$ and $R_{n}$ varied directly with fertilization from low to high treatment. However, after $6 \mathrm{wk}$ of high nutrient dosage, community production collapsed as predicted in the so called 'push-pull' scheme proposed by Odum et al. (1979) for 'enrichment stresses'. In this experiment there was a discontinuity in the otherwise direct relationship between fertilization and production as the system changed structure with the loss of submersed vascular plants. Similar patterns of community production in nutrient enriched ponds have been observed elsewhere (e.g. Hepher 1962).

The reproductive strategies of submersed vascular plants include sexual mechanism with fruit (seed) production during the summer, and asexual formation of overwintering buds or turions (Hutchinson 1975). Potamogeton perfoliatus and Ruppia maritima are generally perennial plants in which most new shoots emerging at the beginning of the growing season are from asexually produced propagules rather than seeds (e.g. Arbor 1920, Verhoeven 1979, Rogers \& Breen 1980). A survey of below-ground vegetation in our experimental ponds during November 1981 revealed that the mean below-ground biomass was about $25 \mathrm{~g}$ dry wt $\mathrm{m}^{-2}$ in low and medium nutrient ponds and negligible in the high nutrient treatments. In May of the subsequent growing season, plant shoots were very sparse in one and absent in the other high fertilization pond, whereas shoots were abundant for all the other ponds. Under high nutrient conditions, algal growth and shading of vascular plants resulted in plant production below compensation levels (see $P_{a}: R_{n}$ for plants with heavy epiphytic colonization; Table 1). This may explain the early senescence (fall die-back) observed for plant populations under heavy fertilization. Thus, decreased translocation of fixed carbon to below-ground stocks and overwintering buds (Harrison 1978) would explain the reduced propagation success evident in the following spring.

Thus, reproductive failure may be mediated by a casual chain involving nutrient enrichment, algal growth, shading of vascular plants, reduced macrophyte production, and decreased energy partitioned to propagative structures. This postulated relationship suggests that the dwindling populations of submersed plants in shallow estuarine systems such as Chesapeake Bay (Orth \& Moore 1983) would involve decreased net production and attendant reproductive success ultimately resulting from nutrient enrichment.

Acknowledgements. We thank W. Goldsborough, L. Winchell and D. Fisher for assistance in sampling and analysis; P. Dark and P. Estes helped with the productivity studies. J. Gilliard and A. R. McGinn typed the manuscript, and J. Metz prepared the figures. This study was funded by grants from the US Environmental Protection Agency Nos R805932010 and X003248010.

\section{LITERATURE CITED}

Arbor, A. (1920). Water plants, A study of aquatic angiosperms. Cambridge University Press, Cambridge

Banse, K., Falls, C. P., Hobson, L. A. (1963). A gravimetric method for determining suspended matter in seawater using Millipore filters. Deep Sea Res. 10: 639-642

Bannister, T. T. (1974). A general theory of steady state phytoplankton growth in a nutrient saturated mixed layer. Limnol. Oceanogr. 19: 13-30

Bayley, S., Stotts, V. D., Springer, P. F., Steenis, J. (1978). Changes in submerged aquatic macrophyte populations at the head of Chesapeake Bay, 1958-1975. Estuaries 1: $73-84$

Borum, J., Wium-Anderson, S. (1980). Biomass and production of epiphytes on eelgrass (Zostera marina L.) in the

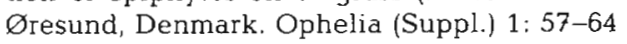

Bulthuis, D. A., Woelkerling, W. J. (1983). Biomass accumulation and shading effects of epiphytes on leaves of the seagrass, Heterozostera tasmanica, in Victoria, Australia. Aquat. Bot. 16: 137-148

Cambridge, M. L. (1979). Cockburn Sound study technical report on seagrass. Department of Conservation and Environment, Western Australia. Rep. No. 7 
Cattaneo, A., Kalff, J. (1980). The relative contribution of aquatic macrophytes and their epiphytes to the production of macrophyte beds. Limnol. Oceanogr. 25: 280-289

Copeland, B. J., Duffer, W. R. (1964). Use of a clear plastic dome to measure gaseous diffusion rates in natural waters. Limnol. Oceanogr. 9: 494-499

Dale, H. M., Miller, G. E. (1978). Changes in the aquatic macrophyte flora of Whitewater Lake near Sudbury, Ontario from 1947 to 1977. Can. Fld Nat. 92: 264-270

Den Hartog, C., Polderman, P. J. G. (1975). Changes in seagrasses populations of the Dutch Waddenzee. Aquat. Bot. 1: $141-147$

Edmondson, W. T. (1955). Factors affecting productivity in fertilized salt water. Deep Sea Res. 3: 451-464

Environmental Protection Agency (1979). Methods for chemical analysis of water and wastes. USEPA-600/4-79-020, Cincinnati, Ohio

Goldsborough, W. J. (1983). Response of the submerged vascular plant, Potamogeton perfoliatus L., to variable light regimes in an estuarine environment. M.S. thesis, University of Maryland

Harlin, M. M., Thorne-Miller, B. (1981). Nutrient enrichment of seagrass beds in a Rhode Island coastal lagoon. Mar. Biol. 65: 221-229

Harrison, P. G. (1978). Patterns of uptake and translocation of ${ }^{14} \mathrm{C}$ by Zostera americana den Hartog in the laboratory. Aquat. Bot. 5: 93-97

Hepher, B. (1962). Primary production in fishponds and its application to fertilization experiments. Limnol. Oceanogr. 7: 131-136

Howard-Williams, C. (1981). Studies on the ability of a Potamogeton pectinatus community to remove dissolved nitrogen and phosphorus compounds from lake water. $J$. appl. Ecol. 18: 619-637

Hutchinson, G. E. (1975). A treatise in limnology, Vol. 3 Limnological botany. John Wiley, New York

Jupp, B. P., Spence, D. H. N. (1977a). Limitations on macrophytes in a eutrophic lake, Loch Leven. I. Effects of phytoplankton. J. Ecol. 65: 175-186

Jupp, B. P., Spence, D. H. N. (1977b). Limitations of macrophytes in a eutrophic lake, Loch Leven. II. Wave action, sediments, and waterfowl grazing. J. Ecol. 65: 431-446

Kemp, W. M., Boynton, W. R. (1980). Influence of biological and physical factors on dissolved oxygen dynamics in an estuarine system. Estuar. coast. mar. Sci. 11: 407-431

Kemp, W. M., Boynton, W. R., Stevenson, J. C., Means, J. C. (ed.) (1981). Submerged aquatic vegetation in Chesapeake Bay. University of Maryland Center for Environmental and Estuarine Studies, Ref. No. HPEL-8128

Kemp, W. M., Boynton, W. R., Twilley, R. R., Stevenson, J. C., Means, J. C. (1983). The decline of submerged vascular plants in Chesapeake Bay: A summary of results concerning possible causes. Mar. Techn. Soc. J. 17: 78-89

Kemp, W. M., Boynton, W. R., Twilley, R. R., Stevenson, J. C. Ward, L. G. (1984). Influences of submersed vascular plants on ecological processes in upper Chesapeake Bay. In: Kennedy, $V$ (ed.) The estuary as a filter. Academic Press, New York, p. 367-393

Lewis, M. R. (1980). An investigation of some homeostatic properties of model ecosystems in terms of community metabolism and component interactions. M. Sc thesis, University of Maryland, College Park

Lewis, M. R., Kemp, W M., Cunningham, J. J., Stevenson, J. C. (1982). A rapid technique for preparation of aquatic macrophyte samples for measuring ${ }^{14} \mathrm{C}$ incorporation. Aquat. Bot. 13: 203-207
Lind, C. T., Cottam, G. (1969). The submersed aquatics of University Bay: A study in eutrophication. Am. Midl. Nat. 81: 353-369

Menzie, C. A. (1979). Growth of the aquatic plant Myriophyllum spicatum in a littoral area of the Hudson River estuary. Aquat. Bot. 6: 365-375

Moss, B. (1976). The effects of fertilization and fish on community structure and biomass of aquatic macrophytes and epiphytic algal populations: an ecosystem experiment. J Ecol. 64: 313-342

Mulligan, H. F., Baranowski, A. (1969). Growth of phytoplankton and vascular aquatic plants at different nutrient levels. Verh. int. Verein. Limnol. 17: 802-810

Mulligan, H. F., Baranowski, A., Johnson, R. (1976). Nitrogen and phosphorus fertilization of aquatic vascular plants and algae in replicated ponds. I. Initial response to fertilization. Hydrobiologia 48: 109-116

Nixon, S. W., Oviatt, C. A. (1972). Preliminary measurements of midsummer metabolism in beds of eelgrass, Zostera marina. Ecology 53: 150-153

O'Brien, W. J., DeNoyelles, Jr., F. (1974). Relationship between nutrient concentration, phytoplankton density, and zooplankton density in nutrient enriched experimental ponds. Hydrobiologia 44: 105-125

Odum, E. P., Finn, J. T., Franz, E. H. (1979). Perturbation theory and the subsidy-stress gradient. Bioscience 29: $349-352$

Odum, H. T., Hoskin, C. M. (1958). Comparative studies on the metabolism of marine waters. Publs. Inst. mar. Sci. Univ. Tex. 6: 159-170

Orth, R. J., Moore, K. A. (1983). Submerged aquatic vegetation of the Chesapeake Bay: Past, present and future. Science 222: 51-53

Penhale, P. (1977). Macrophyte-epiphyte biomass and productivity in an eelgrass (Zostera marina) community. J. exp. mar. Biol. Ecol. 26: 211-224

Penhale, P. A., Smith, W. O. (1977). Excretion of dissolved organic carbon by eelgrass (Zostera marina) and its epiphytes. Limnol. Oceanogr 22: 400-407

Perés, J. M., Picard, J. (1975). Causes de la rarefaction et de la disparition des herbiers de Posidonia oceanica sur les cotes francaises de la Mediterranee. Aquat. Bot. 1. 133-139

Phillips, G. L., Eminson, D., Moss, B. (1978). A mechanism to account for macrophyte decline in progressively eutrophicated freshwaters. Aquat. Bot. 4: 103-126

Rogers, K. H., Breen, C. M. (1980). Growth and reproduction of Potamogeton crispus in a South African lake. J. Ecol. 68: 561-571

Riley, G. A. (1956). Oceanography of Long Island Sound, 1952-1954. II. Physical Oceanography. Bull. Bingham oceanogr. Coll. 15: 15-46

Ryan, J. B., Riemer, D. N., Toth, S. J. (1972). Effects of fertilization on aquatic plants, water, and bottom sediments. Weed Sci. 20: $482-486$

Sand-Jensen, K. (1977). Effect of epiphytes on eelgrass photosynthesis. Aquat. Bot. 3: 55-63

Sand-Jensen, K., Borum, J. (1983). Regulation of growth of eelgrass (Zostera marina L.) in Danish coastal waters. Mar. Techn. Soc. J., 17: 15-21

Sand-Jensen, K., Sondergaard, M. (1981). Phytoplankton epiphyte development and their shading effect on submerged macrophytes in lakes of different nutrient status Int. Revue ges. Hydrobial. 66: 529-552

Sand-Jensen, K., Prahl, C., Stockholm, H. (1982). Oxygen release from roots of submerged aquatic macrophytes. Oikos 38: 349-354 
Scott, B. D. (1978). Phytoplankton distribution and light attenuation in Port Hacking estuary. Aust. J. mar Freshwat. Res. 29: 31-44

Shoaf, W. T., Lium, B. W. (1976). Improved extraction of chlorophyll $a$ and $b$ from algae using dimethyl sulfoxide. Limnol. Oceanogr 21: 926-928

Smith, E. V., Swingle, H. S. (1941). The use of fertilizer for controlling several submerged aquatic plants in ponds. Trans. Am. Fish. Soc. 71: 94-101

Staver, K., Kemp, W M., Boynton, W R. (1981). Interactions between macrophytes and their epiphytic communities as related to plant distribution and abundance in the Chesapeake Bay. In: Kemp, W. M., Boynton, W. R., Stevenson, J. C., Means, J. C. (ed.) Submerged aquatic vegetation in Chesapeake Bay. University of Maryland, Cambridge, Center for Environmental and Estuarine Studies, Ref. No. HPEL-81-28

Staver, K. W. (1984). Responses of epiphytic algae to nitrogen and phosphorus enrichment and effects on productivity of the host plant, Potamogeton perfoliatus L., in estuarine waters. M.S. thesis, University of Maryland, College Park

Stevenson, J. C., Confer, N. M. (1978). Summary of available information on Chesapeake Bay submerged vegetation. Fish and Wildlife Service, Office of Biological Services, 78/66.

Strickland, J. D. H., Parsons, T R. (1972). A practical hand- book of seawater analysis, 2nd ed. Fisheries Research Board of Canada Bulletin 167

Stuckey, R. L. (1978). The decline of lake plants. Nat. Hist. 87 : 66-69

Thayer, G. W., Adams, S. M., LaCroix, M. W. (1975). Structural and functional aspects of a recently established Zostera marina community, In: Cronin, L. E. (ed.) Estuarine research. Academic Press, New York, p. 518-540

Verhoeven, J. T. A. (1979). The ecology of Ruppia-dominated communities in Western Europe. I. Distribution of Ruppia representatives in relation to their autecology. Aquat. Bot. 6: $197-268$

Ward, L. G., Kemp, W. M., Boynton, W. R. (1984). The influence of waves and seagrass communities on suspended sediment dynamics in an estuarine embayment. Mar. Geol. 59: 85-103

Westlake, D. F. (1978). Rapid exchange of oxygen between plant and water, Verh. Internat. Verein. Limnol. 20: 2362-2367

Wetzel, R. L., Penhale, D. A. (1983). Production ecology of seagrass communities in the lower Chesapeake Bay. Mar. Techn. Soc. J. 17: 22-31

Woad, E. J. F., Odum, W. E., Zieman, J. C. (1969). Influence of seagrasses on the productivity of coastal lagoons. In: Lagunas Costeras. UN Simposio Mam. Simp. Intern. Lagunas Costeras, Mexico, p. 495-502

This paper was presented by Professor S. W. Nixon; it was accepted for printing on February 25, 1985 